\title{
Economics
}

2017; 6(4): 44-47

http://www.sciencepublishinggroup.com/j/eco

doi: 10.11648/j.eco.20170604.11

ISSN: 2376-659X (Print); ISSN: 2376-6603 (Online)

\section{An Analysis of Dual Class Equity System - Taking Vanke as an Example}

\author{
Gu Yu, Wang Boyu
}

Department of Accounting, Beijing Wuzi University, Beijing, China

Email address:

wangboyu19936@163.com (Wang Boyu)

To cite this article:

Gu Yu, Wang Boyu. An Analysis of Dual Class Equity System - Taking Vanke as an Example. Economics. Vol. 6, No. 4, 2017 , pp. 44-47. doi: 10.11648/j.eco.20170604.11

Received: March 22, 2017; Accepted: June 30, 2017; Published: August 11, 2017

\begin{abstract}
The acquisition of Vanke Company by Baoneng group has aroused discussions between the theoretical circle and the real world on the dual class equity system. The development of multi-level ownership structure is a challenge and an opportunity for China's capital market. To research the dual class equity system in the angle of top-level design, we ought to make a change in giving the high-tech, high hit, and blue chip companies the choice of ownership structure in order to adapt the fierce competition environment. the dual class equity system reform level include the strict standards, regulate the entry criteria; strict rules of information disclosure mechanism, guarantee transparency of information and fair environment; defining the subject of management, improve the protection of small investors interest mechanism. We should make a useful exploration of the dual ownership system and continuously promote the reform of the shareholding structure in China.
\end{abstract}

Keywords: Ownership Structure, Dual Class Equity System, Vanke

\section{Introduction}

The dual ownership system is a mature company shareholding system in western countries, but in China double ownership system has not been applied and norms, existing dispersed ownership structure in some listed companies, the listed companies will face the risk of acquisition of other listed companies, whether this behavior is well intentioned or malicious acquisition. The most important point that the dual ownership system from single ownership system is: dual ownership system with the shares of different rights, while the traditional ownership system is the same rights, specifically, the dual ownership system is the issuance of shares in the stock divided into A and B shares, A shares issued to specific groups of public common stock, mainly the public and institutional investors, the stock is only one vote or not vote; B is only in the internal management issue that generally not traded, but this vote per share has several times in the ordinary shares. The same rights is based on the perspective of equal shares, each share represents the same rights and obligations, attaches great importance to the protection of the interests of small shareholders is not damaged, maintain the stability of the capital market, Vanke Company is the earliest real estate listed company in China, but the ownership structure of Vanke is not centralized. This paper analyzes the applicability of dual equity structure in China with the example of Bao company and Vanke Company.

\section{China Listed Companies Implementing Dual Class Equity System}

Alibaba is one of the earliest listed companies to implement the Dual Class Equity System in China. Alibaba launched the lake partner system at the beginning of the list, according to the partner system of Alibaba, the partner has a unique right to nominate the majority of directors of the board, but need go through the approval of shareholders. If the Alibaba partner was not nominated directors by shareholders, or for any reason left the board. the directors of Alibaba partners have the right to appoint another person to act as a temporary shareholders, until the next annual general meeting. Alibaba's partner system is a dual ownership structure, but the partner system make adaptive changes in order to listed in Hongkong, this system is not from the allocation of equity ratio to make strict requirements, which is to hold and founder of Alibaba shares had little direct contact, at this stage the Alibaba continues to have financing and expansion. From the initial information 
provider, e-commerce platform to develop a large data cloud service platform Internet plus environment, financing scale expanding greatly diluted the proportion of shares held by the founder, but founder directly owns most of the right to nominate directors, and the founder can nominate their own directors, while retaining the right to nominate other shareholders to the board of directors. the board of this design will not change in the structure for a long time, although the founder of the team held a total of about $13 \%$ of the shares, but the business decision-making power to control the Alibaba, Partner system of Alibaba is separation of profit distribution right partner system and voting rights.

The other two well-known listed companies are Baidu and Jingdong. These high-tech listed companies have strong control over equity, which is inseparable from the high growth and high innovation of these companies. Baidu IPO launched the "Kraft plan" was intended to prevent a hostile takeover, the stock is divided into class A shares and class B shares, the B shares have the right to vote 10 times in class A shares, shares held by the founder of B shares, so the founder at the general meeting of shareholders to vote will have absolute control right, specifically as long as the founder holds more than $11.3 \%$ of B shares will control the company Baidu, the two founders Robin $\mathrm{Li}$ and $\mathrm{Xu}$ Yong hold $34 \%$ shares together, thus they control the company firmly. Jingdong listed on NASDAQ in the United States in 2014, issued a Class A and class B stock, Liu Qiangdong the founder of Jingdong has the class B shares of all the shares and B shares can be converted into class A shares, class B shares have 20 times the class A shares super voting rights at the Jingdong IOP, although the proportion of founder Liu Qiang East Equity accounted for only 20.66\% however, it accounted for $83.7 \%$ of the vote, Liu Qiangdong, control of the Jingdong through the implement the dual ownership structure.

\section{Taking Vanke as an Example}

The acquisition of Vanke Company by Bao company is a typical case. With the rapid development of Internet technology, more and more ecological Chinese in the high-tech listed companies seeking overseas listing, on the one hand, caused by the loss of high quality resources, on the other hand to the new problems of governance on the ownership structure of Listed Companies in the company law of our country, how to put forward a double equity system under the framework of the existing system? how to regulate the operation and practice of dual equity system? This is an urgent problem, a surge of power under the conditions of the Securities Regulatory Commission published "preferred stock pilot management approach", the holders of preferred stock is superior to ordinary shareholders of profits and distribution of surplus property, but the company will participate in the rights policy management limited, a listed company may issue preference stocks, unlisted public company may issue preference shares of non-public, this is actively exploring multi-level equity structure. Dual ownership structure can not only maintain company's control of the founding team, but also can prevent malicious takeover effectively.
The Figuer 1 use Vanke annual data, study Baoneng four placards become Vanke's largest shareholder, and called for the removal of Vanke management process:

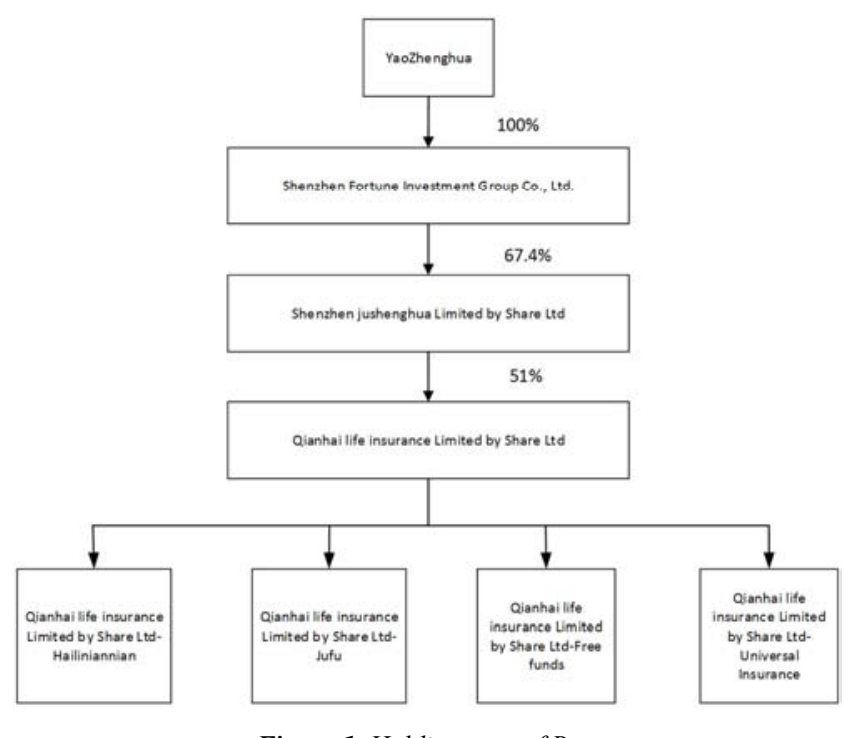

Figure 1. Holding map of Bao.

Bao can be the first time placards in July 10, 2015, Qianhai life insurance, Shenzhen stock exchange centralized trading Vanke A shares purchased 552727926 shares, accounting for $5 \%$ of the total share capital of vanke. In July 2015 24, Boland department second placards, Qianhai life centralized trading holdings Vanke A shares 102945738 shares, accounting for $0.93 \%$ of the total share capital of Vanke, huge Shenghua centralized trading purchase Vanke A shares 449615060 shares, accounting for $4.07 \%$ of the total share capital of vanke.

In August 201526 continue to holdings of Vanke, Qianhai life centralized auction holdings Vanke A shares 80203781 shares, accounting for $0.73 \%$ of the total share capital, huge Shenghua margin to buy 9316800 shares of the total share capital of $0.08 \%$, through the exercise of return swap holds 467138612 shares, accounting for $4.23 \%$ of the total share capital. In November 20, 2015, the Bao department third placards, huge Shenghua through centralized auction and commodity trading holdings Vanke A shares 331716907 shares, financing margin return swap Holdings 37357310 shares, holdings of 556986255 shares, Qianhai life holds 735877445 shares of China Vanke A, this huge Shenghua and Qianhai life together hold Vanke A shares 1661947917 shares, representing the total share capital of Vanke $15.04 \%$.

In December 4, 2015, the Bao department Fourth placards, huge Shenghua asset management plan through centralized auction holdings Vanke A shares 549091001 shares, accounting for $4.969 \%$ of the total share capital, this Bao can together hold Vanke A shares 2211038918 shares, accounting for $20.008 \%$ of the total equity of Vanke, as of December 31, 2015, Huarun Holdings Vanke A shares $15.23 \%$, Bao more than Huarun to become the largest shareholder of Vanke's worthy of the name. Figures 2 and 3 show that Bao become the largest shareholder of Vanke's top ten equity holdings. 


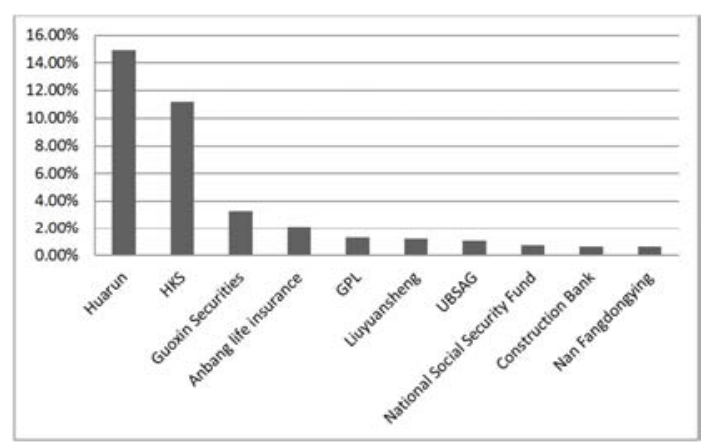

Figure 2. Vanke equity holdings at the end of 2014.

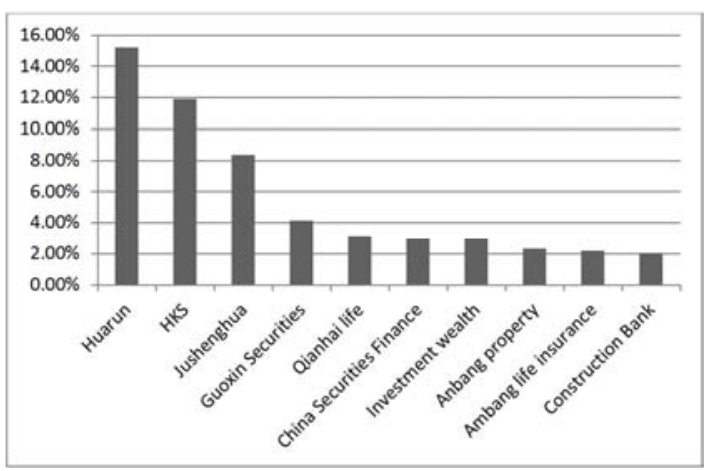

The ownership structure of Vanke dispersed to Bao can continue to holdings of shares in the opportunity, chairman Wang Shi held 7617201 shares of China Vanke, President Yu Liang holds 7306245 shares, Vanke management total only holds 21 million 131 thousand and 700 shares, including Vanke founder and chairman Wang Shi, Vanke management to Bao holdings Vanke, in the same stock with the right stock system under the management of Vanke layer cannot change Bao to become the current situation of the first largest shareholder, a number of companies listed in mainland China Vanke as the earliest has a good reputation in the market and management team, since its establishment in 1984 Chinese today has become the largest professional residential development companies and blue chip representative. Vanke 2009-2015 part of the financial data can be seen from table, net profit and total operating income increased year by year, the average net profit year-on-year growth rate reached $24.43 \%$, an average annual revenue growth rate of $25.88 \%$, Vanke current management good inheritance start-up company philosophy and values, to fulfill the responsibility although the ownership and obligation itself, but still rely on excellent management and internal control to capital market wealth.

Figure 3. Vanke equity holdings at the end of 2015.

Table 1. Vanke part earnings data.

\begin{tabular}{llllllll}
\hline year & $\mathbf{2 0 0 9}$ & $\mathbf{2 0 1 0}$ & $\mathbf{2 0 1 1}$ & $\mathbf{2 0 1 2}$ & $\mathbf{2 0 1 3}$ & $\mathbf{2 0 1 4}$ \\
\hline Net profit & 532973.77 & 728312.70 & 962487.53 & 1255118.24 & 1511854.94 & 1574545.41 \\
Operating income & 4888101.3 & 5071385.1 & 7178274.9 & 10311624.5 & 13541879.1 & 14638800.4 \\
EPS & 3.4 & 4.02 & 4.82 & 5.8 & 6.98 & 19554913.0 & 7.99 \\
ROE (\%) & 14.26 & 16.47 & 18.17 & 19.66 & 19.66 & 17.86 \\
\hline
\end{tabular}

After becoming the largest shareholder of China Vanke the Bao recall all management, stakeholders and regulators have different voices, the argument is a Bao after becoming the largest shareholder has the right to propose provisional shareholders meeting put forward the requirements of the board of directors, on the other hand, all the existing directors recall the impact of Vanke and the consequences will bring. As the lack of Vanke original management quality of listed companies will cause the existing capital interests of the chain and fracture property market shocks, performance management of listed companies will also be so removed to a certain extent on the investment confidence in the market, causing investors to worry about the quality of other listed companies, which is the development of a healthy and orderly the capital market is extremely unfavorable.

In China different enterprises have different demands on the dual ownership system in the process of development, the dual ownership system should also introduce. And take advantages of dual ownership system to improve equity structure. The establishment of dual level and multi-level equity system is based on a sound capital market, a good environment for supervision, and perfect information disclosure mechanism. Therefore, the development of double ownership structure should pay more attention to the top-level design, grasp the double ownership structure firmly, overall planning, reform is conducive to corporate governance environment for the development of double ownership system, supporting system research for double equity system strength.

\section{Suggestions on the Development of Dual Class Equity System}

Double ownership structure is a type of equity diversification, the listed companies have to double ownership structure demand, especially high-tech listed companies, research on multi equity system can promote the improvement and development of China's securities market, Chinese starting from the protection of the interests of small investors, continuous improvement of information disclosure the mechanism related to the development of equity, strict system of relevant laws and regulations and standards.

\subsection{System Construction and Information Disclosure}

Establish the strict standards of the dual equity system, this requires our "company law" to promote the reform of the ownership structure actively, accelerate the pace of the pilot preference shares, according to the foreign advanced practice. the pace. American introduction of dual shareholding system also experienced a discussion and controversy, a wave of 
mergers and acquisitions business in 1985, in the face of market environment changing and the need to enhance the competitiveness. the New York stock exchange in the implementation of one right after 60 years agreed to listed companies to issue different voting the right of the stock, to 1992 the New York stock exchange abandoned a shares of a power system officially, high-tech innovation enterprises in accordance with the Relying on Internet plus under the environment of rapid development, but requires a lot of financing has great requirements for the control of listed companies to such standards should be inclined to promote the development of small and medium-sized enterprises, to meet the high record companies in different stages of development needs, On the other hand, information asymmetry is a form of equity asymmetry, reduce and eliminate information asymmetry is the effective measures to protect the interests of minority shareholders under the environment of market economy, must implement the information disclosure mechanism strictly, especially for growth the expansion rate is higher, the blue chip listed companies, accurate and full disclosure of information enhance investor confidence and reduce the agency cost caused by information.

\subsection{Improvement of Investor Protection Mechanism}

Management is a scarce resource. the market will be efficient only a clear management, rights and obligations are clearly defined in the process of constructing the dual ownership in a strong binding force to maintain the decision-making power of managers, on the other hand to keep the unity of responsibility and interests in the right, the introduction of dual ownership system to improve the protection of the interests of the majority of investors mechanism as the premise, the development of China's securities market is not developed, Major shareholders damage the interests of the company. how to protect the interests of small investors is the core of dual ownership structure. Canada introduce double dovetail shares to increase maintenance of outside shareholders' rights; the United States securities group litigation system has become an effective means of small and medium shareholders to protect their rights and interests are not infringed, the number of times of different voting rights provisions into the company's qualification; according to the facts in our country. Based on the internal balance of corporate governance to ensure the use of human resource management and make corresponding restrictions, should be used as points of the reform of the company law comparison and reference.

\section{References}

[1] Li Haiying, Li Shuanghai, Bi Xiaofang. The dual ownership structure under the protection of the interests of small investors, Chinese industrial economy, the case study of Facebook acquisition of WhatsApp [J]. 2017 (01): 174-192.

[2] Hu Panpan. The dual ownership structure system and its legislative introduction [J]. commercial economic research, 2016, (22): 116-117.

[3] Chen Bin. Comment on the reform of dual ownership structure system. Singapore's corporate law perspective, [J]. securities market Herald, 2016, (07): 1.

[4] Peng Peng. Institutional value interpretation and localization approach of dual ownership structure. Taking the partner system of Alibaba group as the breakthrough point [J]. Hebei University of science, 2016, (05): 166-174.

[5] Liu Zongjin. Analysis of the dual ownership structure of overseas listing of Internet based technology companies. Taking Jingdong as an example, [J]. accounting and communication, 2015, (34): 14-16.

[6] Liu Xing, Fu Qiang, Hao Ying. Ultimate controller, agent, two power separation model and private rights of control. [J]. systems engineering theory and practice, 2015, (01): 75-85.

[7] Liu Xing, Fu Qiang, Jiang water. The ultimate property rights under the control of the personal behavior and Governance: a review on the heterogeneous control mechanism of [J]. East China economic management, based on the 2014 (04): 1-7.

[8] Lu Xin, Gong Qiming, Zheng Yangfei. Study on the factors of equity incentive contract and its influencing factors [J]. Journal of Shanxi University of Finance and Economics, 2013, (04): 49-59.

[9] Zhang Lina. Look at the advantages and disadvantages of the dual ownership structure from the Snap listing. [J]. financial industry, 2017, (06): 121-123.

[10] Tang Jingjing [J]. Case of modern business, based on the 2017 Internet companies listed overseas dual ownership structure analysis, (09): 86-87.

[11] Yifei. Vanke equity dispute: trade, opportunity [J]. northern dual ownership structure in 2017 (01): 115-116. 